\title{
PENINGKATAN MOTIVASI HASIL BELAJAR SISWA PADA PEMBELAJARAN PKN DENGAN MENGGUNAKAN METODE TEAMS GAMES TOURNAMENT DI KELAS IV SD NEGERI 060829 MEDAN AMPLAS
}

\author{
Nurmaida Purba \\ Surel: Nurmaida@gmail.com
}

\begin{abstract}
ABSTRAK
Setelah dilakukan Penelitian Tindakan Kelas dengan 3 siklus didapatkan peningkatan motivasi belajar siswa yang sangat memuaskan. Aktivitas siswa dalam konstruktivisme meningkat sangat signifikan $(97,37 \%)$, peningkatan dalam learning community, motivasi belajar, mengemukakan pertanyaan, mengemukakan pendapat, mencatat hal-hal penting, perhatian siswa dalam mengikuti pelajaran, juga mengalami peningkatan $(97,37 \%)$. Peningkatan yang sangat signifikan juga terjadi terhadap hasil belajar siswa, baik secara individual maupun klasikal, terlihat dari nilai yang mereka peroleh sudah di atas kriteria ketuntasan belajar, yaitu 65. Model pembelajaran Teams Games Tournament (TGT) dapat meningkatkan motivasi dan hasil belajar siswa Kelas IV SD Negeri 060829 Medan Kota. pada pembelajaran PKn dengan kompetensi dasar menerapkan HAM.
\end{abstract}

Kata Kunci : Motivasi Belajar, PKn, Teams Games Tournament

PENDAHULUAN

Pelajaran bertujuan

membangun kesadaran siswa tentang

pentingnya nilai-nilai kehidupan

sebagai sebuah proses dari masa kehidupan, masa kini, dan masa depan. Dengan belajar PKn diharapkan juga dapat melatih daya kritis siswa untuk memahami fakta nilai secara benar dengan didasarkan pada pendekatan ilmiah. Menumbuhkan apresiasi dan penghargaan siswa terhadap nilai berbangsa sebagai bukti peradaban hubungan antar manusia. Menumbuhkan kesadaran dalam diri siswa sebagai bagian hubungan yang memiliki rasa bangga dan cinta antar manusia yang dapat diimplementasikan dalam berbagai bidang kehidupan.

Untuk meningkatkan semua tujuan pembelajaran $\mathrm{PKn}$ di atas, tentunya siswa perlu mengikuti kegiatan belajar dan mengajar yang optimal, karena dari proses pembelajaran tersebut diharapkan terjadi perubahan yang relatif permanen terhadap kemampuan, keterampilan, sikap, dan perilaku siswa sebagai akibat dari pengalaman atau pelatihan dalam kegiatan belajar. Agar proses belajar dan mengajar ini dapat mencapai hasil yang optimal, tentu perlu ada sarana pembelajaran yang memadai dan metode

SD Negeri 060829 Medan Amplas 
pembelajaran yang dapat mendukung peningkatan hasil belajar.

Namun pada kenyataannya, berbicara tentang mata pelajaran PKn maka akan muncul kesan pembelajaran yang membosankan, kering, monoton, dan segala bentuk kesan yang kurang menyenangkan, ditambah lagi penampilan guru yang pada waktu mengajar dengan penampilan seadanya tidak menggunakan media pembelajaran minimal peta atau photo dokumentasi. Pembelajaran PKn sering diidentikkan dengan kefasihan bercerita. Hal tersebutlah yang membuat proses belajar PKn yang kurang menyenangkan terjadi.

Masih ditemukan beberapa kelemahan belajar PKn dengan menggunakan metode ceramah (teacher center). Kelemahan tersebut dapat dilihat pada saat berlangsungnya proses pembelajaran di kelas, interaksi aktif antara siswa dengan guru atau siswa dengan siswa jarang terjadi. Siswa kurang terampil menjawab pertanyaan atau bertanya tentang konsep yang diajarkan. Siswa kurang bisa bekerja dalam kelompok diskusi dan pemecahan masalah yang diberikan. Mereka cenderung belajar sendiri-sendiri. Pengetahuan yang didapat bukan dibangun sendiri secara bertahap oleh siswa atas dasar pemahaman sendiri karena siswa jarang menemukan jawaban atas permasalahan atau konsep yang dipelajari.

Evaluasi terhadap hasil belajar siswa Kelas IV SD Negeri 060829 Kec. Medan Kota Tahun Pelajaran 2015/2016 didapatkan kenyataan bahwa dengan pendekatan pembelajaran seperti di atas hasil belajar siswa belum maksimal. Hal ini tampak pada pencapaian nilai akhir siswa. Dalam satu semester siswa yang memperoleh nilai di atas 65 tidak lebih dari 15\%. Rendahnya pencapaian nilai akhir siswa ini menjadi indikasi bahwa pembelajaran yang dilakukan selama ini belum efektif. Nilai akhir dari evaluasi belajar belum mencakup penampilan dan partisipasi siswa dalam pembelajaran, hingga sulit untuk mengukur keterampilan siswa.

Disamping itu, dengan kondisi siswa yang sangat beragam, meliputi perbedaan kemampuan akademik, karakter siswa, jenis kelamin, bahkan perbedaan suku, juga merupakan salah satu kelemahan dalam pembelajaran PKn. Perbedaan tersebut sering menimbulkan kesenjangan antara satu siswa dengan siswa yang lain sehingga mereka cenderung membentuk kelompok dengan teman sebayanya yang mempunyai kesamaan pandangan. Hal ini berpengaruh terhadap aktivitas belajar siswa. Dengan demikian perlu dilakukan pembelajaran yang dapat mengurangi kesenjangan antar siswa, salah 
satunya dengan model pembelajaran kooperatif Teams Games Tournament (TGT), karena dalam pembelajaran ini melibatkan peran siswa sebagai tutor sebaya dan siswa dapat belajar bekerjasama. Menurut Carolyn (1992) dalam Purnamawati (2009:4), "Pembelajaran kooperatif merupakan aktivitas belajar kelompok yang teratur dan terstruktur dan tiap anggota bertanggungjawab untuk kelompoknya, dirinya sendiri serta dimotivasi untuk meningkatkan pembelajaran lainnya."

Dari latar belakang masalah di atas dapat diidentifikasikan beberapa masalah, seperti: (1) pembelajaran PKn terkesan membosankan, kering, dan monoton, (2) penampilan guru yang kurang profesional karena tidak menggunakan media pembelajaran yang sesuai dengan meteri yang diajarkan, (3) pada saat proses belajar berlangsung interaksi antara siswa dan guru tidak terjalin dengan baik, (4) siswa tidak terbiasa belajar dalam kelompok, (5) metode ceramah yang selalu digunakan guru dalam proses belajar mengajar sehingga yang menjadi fokus pembelajaran adalah guru (teacher center), (6) perlunya penggunaan metode pembelajaran yang lain selain model ceramah, misalnya dengan metode Team Games Tournament (TGT).

Adapun tujuan penelitian ini adalah:

a. Untuk mengetahui apakah model pembelajaran Teams Games

Tournament (TGT) ini dapat meningkatkan motivasi belajar siswa.

b. Untuk mengetahui apakah model pembelajaran Teams Games Tournament (TGT) ini dapat meningkatkan hasil belajar siswa.

c. Siswa dapat lebih termotivasi sehingga senang belajar PKn dan dapat memperoleh pengalaman belajar.

d. Guru dapat lebih menambah wawasan tentang strategi pembelajaran PKn dengan menggunakan model-model pembelajaran yang berbeda dari ceramah.

e. Sekolah dapat lebih meningkatkan mutu pendidikan.

f. Kelengkapan usul kenaikan pangkat satu tingkat.

\section{METODE PENELITIAN}

Penelitian dilakukan di SD Negeri 060829 Kec. Medan Kota. Waktu penelitian dilaksanakan pada Semester Ganjil yaitu bulan September s.d Nopember 2016 Tahun Pelajaran 2015/2016.

Subjek dalam penelitian ini adalah seluruh siswa Kelas IV SD Negeri 060829 Kec. Medan Kota sebanyak 38 orang. Objek penelitian ini adalah pembelajaran dengan menggunakan metode pembelajaran Teams Games Tournament (TG7) pada kompetensi dasar menerapkan 
HAM.

Pada pengumpulan data, dalam hal ini penulis sebagai guru PKn dibantu oleh seorang guru PKn lain yang bertindak sebagai observan. Observasi dilakukan pada saat proses pembelajaran berlangsung. Selain itu, peneliti juga melakukan tes. Tes tertulis, terdiri dari pretest dan posttes. Pretest dilakukan untuk melihat kemampuan daya serap siswa terhadap materi pelajaran yang akan disampaikan. Posttes dilakukan untuk melihat hasil akhir kemampuan daya serap siswa dalam menerima seluruh materi pelajaran yang telah disampaikan guru.

Langkah-langkah perencanaan pembelajaran dengan strategi/model Teams Games Tournament (TGT) sebagai berikut:

1. Menyusun rencana pelaksanaan pembelajaran, menyusun soalsoal yang akan digunakan untuk Teams Games Tournament (TGT), menyusun materi diskusi, menyusun posttes, menyusun lembar observasi, membentuk kelompok-kelompok diskusi siswa secara heterogen, masing masing kelompok terdiri dari 5 atau 6 orang. Kompetensi dasar menerapkan HAM dialokasikan waktu sebanyak 3 kali pertemuan (3 x 3 x 45 menit). Pertemuan pertama, kedua, dan ketiga, guru menjelaskan kompetensi dasar, selanjutnya siswa melakukan diskusi kemudian melakukan games dalam bentuk turnamen.

2. Untuk games dalam bentuk turnamen guru menyediakan beberapa kartu pertanyaan untuk pertandingan. Pertandingan dilakukan dengan cara siswa mengambil kartu secara acak. Nomor yang ada pada kartu merupakan nomor pertanyaan yang harus dijawab. Apabila siswa yang mengambil kartu dapat menjawab maka dia harus menyimpan kartunya untuk dihitung pada akhir turnamen. Apabila siswa yang mengambil kartu tidak dapat menjawab maka siswa yang lain dalam satu kelompok turnamen boleh menantang untuk menjawabnya. Penantang yang menjawab dengan jawaban benar akan menyimpan kartunya, sedang yang menjawab dengan jawaban yang salah akan diambil kartu yang telah dimiliki sebelumnya.

3. Pada masing-masing pertemuan juga dilakukan post tes untuk melihat ketuntasan belajar siswa.

4. Melakukan analisis data. Untuk melihat aktivitas siswa maka dilakukan observasi terhadap kegiatan diskusi dan selama berlangsung proses pembelajaran dengan metode Teams Games Tournament (TGT). 


\section{HASIL DAN PEMBAHASAN}

Berdasarkan pengamatan pada saat diskusi dan games berlangsung dengan materi menerapkan HAM, diperoleh data sebagai berikut:

1. Aktivitas siswa menunjukkan bahwa konstruktivisme sangat rendah $(13,16 \%), \quad$ learning community rendah, rata-rata $(19,01 \%)$, dan motivasi juga masih rendah $(21,05 \%)$.

2. Aktivitas siswa mengemukakan pertanyaan masih rendah $(10,53 \%)$ dan mengemukakan pendapat juga masih rendah $(15,79 \%)$.

3. Aktivitas siswa mencatat hal-hal penting masih rendah $(18,42 \%)$.

Dari hasil pengamatan pada Siklus 1, ditemukan beberapa kendala yang berasal dari siswa dan guru, seperti:

1. Guru tidak mempunyai waktu yang cukup untuk menjelaskan metode pembelajaran Teams Games Tournament (TGT) sehingga banyak siswa yang tidak melaksanakannya dengan baik.

2. Pada saat melakukan diskusi, beberapa siswa tidak mempunyai persiapan yang memadai terutama karena kurangnya buku sumber pegangan siswa.

3. Aktivitas siswa dalam diskusi, menjawab pertanyaan, dan memberi ide/gagasan masih kurang.
4. Sebahagian besar siswa masih merasa canggung dan kurang percaya diri pada saat melakukan games.

5. Kurangnya keinginan siswa untuk mencatat dan memahami konsep secara mendalam, terbukti dengan kurangnya catatan penting dalam buku catatan.

6. Rata-rata hasil belajar siswa masih dalam taraf kategori rendah.

Setelah siswa melaksanakan kegiatan Teams Games Tournament (TGT) maka dilakukan post tes untuk melihat kemampuan daya serap siswa. Diberikan instrumen dalam bentuk isian singkat sebanyak 20 soal, dan nilai masing-masing skor adalah:

- Nomor soal 1 s.d. 5 nilai 4

- Nomor soal 6 s.d. 10 nilai 5

- Nomor soal 11 s.d. 15 nilai6

- Nomor soal 16 s.d.20 nilai 7

Dapat dilihat bahwa dari 38 orang siswa yang mengikuti posttes, tidak ada satu orang pun yang mencapai taraf ketuntasan belajar. Seluruh nilai siswa berada di bawah persentase daya serap yang telah ditetapkan yaitu 65 .

Berdasarkan hasil pengamatan kegiatan Teams Games Tournament (TGT) dan hasil post tes siswa pada siklus 1 untuk ketuntasan belajar siswa secara individual dan klasikal 
masih sangat tidak memuaskan karena keseluruhan siswa tidak mencapai nilai ketuntasan belajar.

Dalam penelitian tindakan kelas ini perlu dilakukan perbaikan atas tindakan yang dilaksanakan, diantaranya sebagai berikut:

1. Guru harus lebih mensosialisasikan Teams Games Tournament (TGT) kepada siswa secara terperinci sehingga siswa tidak lagi merasa canggung untuk melakukan kegiatan tersebut.

2. Guru harus lebih memotivasi siswa untuk mencari bahanbahan yang terkait dengan materi mengidentifikasi menerapkan HAM melalui media pembelajaran lainnya, seperti internet.

3. Pada saat menjelaskan materi pembelajaran, guru harus memberi penjelasan yang lebih serius kepada materi yang dianggap penting dengan selalu mengulang-ulang materi tersebut.

4. Guru harus mengingatkan siswa agar mencatat setiap materi penting tanpa harus mengandalkan buku pegangan saja karena dengan mencatat kembali diharapkan siswa dapat lebih mengingat materi yang dipaparkan guru.

5. Dalam menjelaskan materi pembelajaran guru harus dapat membuat suasana kelas menyenangkan, belajar tetap serius namun suasana harus dibuat santai, siswa dilibatkan dalam proses pembelajaran sehingga pada saat melakukan presentasi siswa tidak lagi merasa malu/canggung.

Berdasarkan hasil tindakan pada siklus 2 dengan bahan kajian mengidentifikasi menerapkan HAM diperoleh data sebagai berikut:

1. Terjadi peningkatan aktivitas belajar siswa, dibandingkan dengan siklus 1. Aktivitas siswa dalam konstruktivisme meningkat $(26,32 \%)$, terjadi juga peningkatan dalam learning community ratarata $(58,55 \%)$, untuk motivasi belajar juga mengalami peningkatan $(57,89 \%)$.

2. Aktivitas siswa dalam mengemukakan pertanyaan meningkat $(36,84 \%)$ sedangkan dalam mengemukakan pendapat juga meningkat (42,11\%). Aktivitas siswa dalam mencatat hal-hal penting meningkat $(55,26 \%)$, sedangkan perhatian siswa dalam mengikuti pelajaran juga mengalami peningkatan $(31,58 \%)$.

Setelah dilakukan perbaikan atas tindakan yang dilaksanakan pada siklus 1, maka mulai tampak peningkatan pada kegiatan diskusi siswa walaupun peningkatan tersebut masih kurang memuaskan. Konstruktivisme dan learning comunity masih rendah 
peningkatannya, namun khusus untuk kerjasama dan keaktifan dalam kelompok sudah mulai memperlihatkan peningkatan yang lebih baik. Siswa mulai menyadari bahwa jika tidak terjalin kerja sama yang baik dalam kelompoknya, maka hasil yang diperoleh dalam kegiatan games tidak akan memuaskan. Perbaikan lain yang dilakukan, seperti: (1) penjelasan yang lebih mendalam tentang metode pembelajaran dengan Teams Games Tournament (TGT), (2) siswa mendapatkan bahan-bahan pelajaran yang terkait dengan materi dari internet, (3) suasana kelas juga sudah lebih menyenangkan karena pembelajaran berlangsung dengan serius namun santai, maka dapat dilihat aktivitas belajar siswa sudah mengalami peningkatan.

Kegiatan selanjutnya pada siklus 2 adalah melakukan posttes untuk melihat kemampuan daya serap siswa. Seperti pada siklus 1 maka diberikan posttes pada akhir pertemuan kedua, jumlah soal dan teknik penilaian juga tetap sama. Skor yang diperoleh siswa dan persentase ketuntasan diketahui bahwa terjadi peningkatan terhadap hasil post tes siswa, baik secara individual maupun klasikal. Namun, peningkatan tersebut masih belum memuaskan karena hanya 15 orang siswa yang sudah mencapai kriteria ketuntasan belajar sedangkan 23 orang lagi masih belum mencapai kriteria ketuntasan.

Hasil pengamatan aktivitas siswa selama berlangsungnya diskusi dan games dalam turnamen serta berdasarkan hasil persentase ketuntasan belajar pada siklus 2, masih ditemukan beberapa kelemahan, seperti : (1) diskusi yang dilakukan siswa masih belum lancar, masih ada beberapa siswa yang hanya duduk diam mendengarkan, (2) pada saat games dalam turnamen dilakukan, beberapa siswa tidak dapat menjawab pertanyaan dengan benar, (3) beberapa orang siswa hanya mengandalkan buku pegangan saja sebagai pedoman dalam mempelajari materi Kesadaran Kebangsaan di Asia Afrika, padahal guru sudah menganjurkan untuk mencari bahan melalui media internet, (4) suasana pembelajaran yang dilakukan dengan santai namun serius, disalahartikan oleh beberapa siswa dengan cara bermain-main, bercakap-cakap, disaat teman yang lain serius melaksanakan diskusi ataupun games.

Untuk memperbaiki kelemahan pada siklus 2 maka dilakukan lagi perbaikan tindakan pada siklus 3, kemudian diperoleh data sebagai berikut:

1. Peningkatan aktivitas belajar siswa menjadi sangat memuaskan, dibandingkan dengan siklus 2 .

2. Aktivitas siswa dalam 
konstruktivisme meningkat (97,37\%), terjadi juga peningkatan dalam learning community rata-rata $(99,34 \%)$, untuk motivasi belajar juga mengalami peningkatan (100\%).

3. Aktivitas siswa dalam mengemukakan pertanyaan meningkat (100\%) sedangkan dalam mengemukakan pendapat juga meningkat (100\%).

4. Aktivitas siswa dalam mencatat hal-hal penting meningkat (100\%), sedangkan perhatian siswa dalam mengikuti pelajaran juga mengalami peningkatan $(100 \%)$.

Pengamatan terhadap aktivitas siswa selama diskusi dan games berlangsung pada siklus 3 mernperlihatkan hasil yang sangat memuaskan. Untuk semua poin aktivitas siswa mengalami peningkatan. Hanya dua orang siswa saja yang belum menunjukkan aktivitas positif, khususnya pada poin konstruktivisme dan menemukan/ memecahkan masalah. Siswa selalu duduk diam tanpa mau ikut serta dalam diskusi yang berlangsung, bahkan terkesan tidak mau tahu. Walaupun sudah diingatkan oleh guru, namun sikap siswa tetap tidak berubah.

Kegiatan selanjutnya pada siklus 3 adalah melakukan posttes untuk melihat kemampuan daya serap siswa. Jumlah soal dan teknik penilaian juga tetap sama dengan siklus 1 dan 2. Skor yang diperoleh siswa dan persentase ketuntasan dapat dilihat bahwa pada siklus 3 persentase ketuntasan belajar juga sudah meningkat jauh lebih baik, 36 orang siswa sudah mendapat nilai di atas 65 Namun, masih ada dua orang siswa yang belum mencapai nilai sesuai dengan kriteria ketuntasan belajar. Siswa yang kurang aktif pada saat diskusi dan games adalah siswa yang persentase ketuntasan belajarnya masih di bawah 65 .

Berdasarkan data yang diperoleh pada siklus 1, 2, dan 3, dapat dilihat adanya peningkatan motivasi dan hasil belajar PKn dengan menggunakan metode Teams Games Tournament (TGT), yang ditentukan berdasarkan ketuntasan belajar siswa secara individual dan klasikal serta aktivitas siswa terhadap kegiatan belajar mengajar.

\section{SIMPULAN}

Adapun simpulan dalam penelitian ini adalah:

1. Aktivitas siswa dalam konstruktivisme meningkat sangat signifikan $(97,37 \%)$, peningkatan dalam learning community juga semakin baik (97,37\%), untuk motivasi belajar juga mengalami peningkatan $(100 \%)$.

2. Aktivitas siswa dalam mengemukakan pertanyaan meningkat $(100 \%)$ sedangkan 
dalam mengemukakan pendapat juga meningkat (100\%).

3. Aktivitas siswa dalam mencatat hal-hal penting meningkat (100\%), sedangkan perhatian siswa dalam mengikuti pelajaran juga mengalami peningkatan $(100 \%)$.

4. Terjadi peningkatan yang sangat memuaskan terhadap hasil belajar siswa setelah dilakukan post tes, baik secara individual maupun klasikal, terlihat dari nilai yang mereka peroleh sudah di atas 65 .

5. Model pembelajaran Teams Games Tournament (TGT) dapat meningkatkan motivasi belajar siswa Kelas IV SD Negeri 060829 Kec. Medan Kota pada pembelajaran PKn.

6. Model pembelajaran Teams Games Tournament (TGT) dapat meningkatkan hasil belajar siswa dilihat dari peningkatan hasil belajar siswa dalam proses pembelajaran.

\section{DAFTAR RUJUKAN}

Alfian, Magdalia, dkk. 2006. PKn untuk SMA dan MA Kelas $X I$. Jakarta: ESIS.

Dimiyati dan Mudjono. 1984. Belajar dan Pembelajaran. Jakarta: Proyek Pembinaan dan Peningkatan Mutu Kependidikan Dirjen Depdikbud.
Gibson, Ivancevich, Donnelly. 1997. Organisasi: Perilaku Struktur Proses, Edisi Kelima/Jilid 1. Jakarta: Erlangga.

Uno, Hamzah B. 2008. Teori Motivasi dan Pengukuran Analisis di Bidang Pendidikan. Jakarta: Bumi Aksara. 